Article

\title{
Study on the Environmental Education Demand and Environmental Literacy Assessment of Citizens in Sustainable Urban Construction in Beijing
}

\author{
En $\mathrm{Wu}^{1, *}$, Jing-Qi Cheng ${ }^{2}$ and Jia-Bao Zhang ${ }^{1}$ \\ 1 School of Landscape Architecture, Beijing Forestry University, Beijing 100083, China; mint96@bjfu.edu.cn \\ 2 Jingdu Fengjing Ecotourism Planning and Design Institute, Beijing 100083, China; 3150494@bjfu.edu.com \\ * Correspondence: wunen@bjfu.edu.cn
}

Received: 23 November 2019; Accepted: 24 December 2019; Published: 27 December 2019

check for updates

\begin{abstract}
In the process of sustainable urban construction, citizens' environmental literacy is a decisive factor, and environmental education is an important factor affecting the former's level. Therefore, by determining the environmental literacy and environmental education demand of 383 citizens, the conclusion of this study is instructive for sustainable urban construction in China and other developing countries. Further, in the study, data were collected through a paper questionnaire and Statistical Product and Service Solutions (SSPS) software version 25 (IBM Corp, BJ, CHN) was used for data analysis. According to our survey, the average score of Beijing citizens' environmental literacy is 3.77 out of 5, which reflects the necessity to carry out environmental education for the citizen. In order to effectively measure citizens' environmental literacy, we divided the sample population into three groups according to their evaluation scores of environmental literacy. The social demographic characteristics of the high- and middle-scoring groups showed a higher proportion of women and well-educated people. A higher proportion of working or living stability was reflected in the majority of civil servants, staff of citizen institutions, retirees, and housewives. There were more people over the age of 30, most of whom have lived in Beijing for a long time. "Green lifestyle" and "knowledge and skills of environmental protection" were the aspects of environmental education that the sample group of Beijing citizens generally wants to learn. In addition, citizens in the high- and middle-scoring groups are also more interested in "ecological science knowledge", while the low-scoring group is more interested in "the knowledge of environmental factors" and "environmental ethics". The survey respondents showed the highest preference for environmental education (natural education) when participating in outdoor activities, followed by exhibition place and activity, with a relatively low preference for lecture and community activities. Mass media is also an important channel for environmental education, and the use preference and frequency of new media such as MicroBlog, WeChat, and short video applications are much higher than those of traditional media such as television and newspapers.
\end{abstract}

Keywords: sustainable urban development/urban construction; environmental education; environmental literacy

\section{Introduction}

\subsection{Research Background and Significance}

Since its foundation 70 years ago, the People's Republic of China has experienced the largest and fastest urbanization in world history. From 1949 to the end of 2018, the urbanization rate of the permanent resident population gradually increased from $10.64 \%$ to $59.58 \%$. More particularly, 
during the 40 years from 1978 to 2018, the urbanization rate increased by $40 \%$ [1]. Similar to many problems that have arisen in the process of urbanization around the world, China's rapid urbanization process, especially in the past 40 years, has also brought about a series of environmental and social problems, such as traffic congestion and ever-growing quantities of garbage, smog and air pollution issues, over-exploitation of groundwater, water pollution, and the "stagnation" of citizen happiness. As a huge city, with a population of more than 20 million, and the capital of China, Beijing is a representative city for sustainable urban construction. Therefore, how to achieve sustainable development in Beijing has become an urgent concern for both the Chinese government and Beijing residents [2]. In the process of sustainable urban construction, the environmental literacy of citizens is a very important decisive factor. Environmental literacy refers to a system of knowledge, emotions, values, skills, and actions related to the environment and the relationship between humans and the environment [3]. The way in which the government, various public institutions, nongovernmental organizations (NGOs), schools, and even enterprises and commercial institutions carry out environmental education for the citizen is an important factor affecting citizens' environmental literacy. At present, there are few studies on the relationship between sustainable urban construction and public environmental education.

Therefore, this paper takes Beijing as an example to investigate the citizens' environmental literacy level and demand for environmental education in sustainable urban construction, in the hope that the conclusion of the study can be used for reference in China and other developing countries.

\subsection{Research Purpose}

This study divides Beijing citizens into groups with different environmental literacy levels and analyzes the demand for environmental education content and the use preference of mass media so as to provide a summary and foundational public demand for the Beijing government and other public sectors, nongovernmental organizations, and commercial institutions to carry out environmental education.

\subsection{Research Scheme}

We began the paper by introducing the background, purpose, and scheme of the research (Section 1). Then, we analyze related previous studies on the subjects of sustainable cities, environmental literacy, and environmental education. In Section 3, the research method and process are presented. In Sections 4 and 5, we present the corresponding results of this study and further discuss the results through theirn theoretical and practical implications. In Section 6, we provide conclusions and recommendations for environmental education in Beijing. Finally, we provide suggestions for future research (Section 7).

\section{Literature Review}

\subsection{Sustainable Development and Sustainable Cities}

The concept of sustainable cities comes from the theory of sustainable development. While the Industrial Revolution and the scientific and technological revolution in the 20th century promoted the rapid development of human society, they also brought about a series of environmental problems that are not conducive to the development of human society, such as the over-exploitation of resources, environmental degradation, and disorderly urban expansion. In this context, the United Nations held a Conference on the Human Environment in Stockholm, Sweden, in 1972, and the theory of sustainable development was formally discussed by the international community for the first time. The United Nations Conference on Environment and Development (UNCED) published a report named Our Common Future in 1987, which systematically explained sustainable development for the first time, defining it as a development that meets the needs of the present without compromising future generations to meet their needs. Agenda 21, adopted by the United Nations in 1990, marked the 
transition from theory to practice in the context of sustainable development $[4,5]$. The theory of sustainable development was introduced in China in the early 1990s. China first proposed this theory at the Conference on Ministers of Environment and Development of Developing Countries in 1991. Since then, Chinese scholars have applied the concept of sustainable development in many aspects, such as ecological environment protection, urban construction and renewal, and the protection of traditional culture.

Sustainable cities apply the concept of sustainable development to urbanization and urban construction. The purpose of sustainable cities is to solve the problems brought about by urbanization, such as environmental pollution and social inequity. "Sustainable city" was defined by the the Sustainable Cities Programme (SCP) launched by the United Nations Human Settlements Programme (UN-HABITAT) and the United Nations Environment Programme (UNEP) in the early 1990s, and was internationally agreed upon [6]. The definition is as follows: "a sustainable city is a city that has achieved sustainable social, economic, and natural environments. The city's use of resources and the environment is maintained at a sustainable level and has a lasting resistance to potential environmental risks".

In 1991, the Chinese government launched the Conference on Ministers of Environment and Development of Developing Countries. The conference issued the Beijing declaration, which defined sustainable urban construction. In 1994, China formulated and promulgated China Agenda 21, which stated that the goal of sustainable cities in China is "to build cities with reasonable planning and layout. The city has perfect supporting facilities, which can provide convenient work and life. The living environment is clean, beautiful, quiet, and comfortable".

At the macro level, the current research on sustainable cities in Chinese mainly focuses on the theory of sustainable construction, the construction of an evaluation index system, and the types of sustainable cities. The "three-pillar theory" is the most recognized concept of sustainable development in academia. Thus, Chinese scholars' research on sustainable urban construction theory focuses on three aspects: economic, social, and ecological [7]. When Chinese scholars conduct research on the construction of a sustainable city evaluation index system, they mainly focus on the levels of urban construction, social construction, and economic development and environmental protection [8-11]. Chinese scholars have rich research results on sustainable city types, which can be divided into three categories according to the urban development goals: research on healthy and forest cities, with the goal of improving the ecological environment; research on low-carbon and circular economy cities, with the goal of promoting urban transformation or renewal; and research on livable and ecological civilization cities, with the goal of comprehensive development [12]. At the micro level, Chinese scholars' research on sustainable city construction mainly focuses on infrastructure planning, design, and construction, such as studies on communities, parks, and transportation [13-16].

In summary, the sustainable city research of Chinese scholars is mostly carried out from the perspective of the government, while research on the status, role, and participation of citizens is still rare.

\subsection{Environmental Literacy}

In the 1960s, consumerism spread throughout American society, accelerating the predatory development of the natural environment, causing the serious pollution of forests, soil, water, and air [17]. At that time, many scholars believed that environmental pollution was caused by those who were considered to be "environmentally illiterate". Roth, an American scholar, proposed a concept opposed to "environmental illiterates", i.e., environmental literacy, in 1968. To him, environmental literacy referred to the comprehensive quality of knowledge, emotions, values, skills, and actions that people have about the environment and the human-environment relationship [3]. So far, complete agreement on the definition of environmental literacy has not been reached (see Table 1). However, we can see that environmental literacy is not only related to the public's environmental knowledge, values and emotions, but also closely related to their environmental protection behavior. 
Table 1. Summary of environmental literacy concepts [18-22].

\begin{tabular}{|c|c|c|}
\hline Time & Source & Concept \\
\hline 1978 & $\begin{array}{l}\text { Tbilisi Environmental Education } \\
\text { Conference }\end{array}$ & $\begin{array}{l}\text { People with environmental literacy have the following characteristics: (1) perception of } \\
\text { and sensitivity to the overall environment; (2) understanding and experience of } \\
\text { environmental issues; (3) environmental values and caring about the environment; (4) } \\
\text { skills for identifying and solving environmental problems; and (5) participation in } \\
\text { solving environmental problems at all levels. }\end{array}$ \\
\hline 1986 & Hine and Hungerford & $\begin{array}{l}\text { Environmental literacy is an effective trait of a person's view of the environment [7] in } \\
\text { terms of responsible environmental behavior, conscious behavior based on personal } \\
\text { responsibility and values aimed at avoiding or solving environmental problems. }\end{array}$ \\
\hline 1991 & $\begin{array}{l}\text { American Society for Testing } \\
\text { (ASTM) }\end{array}$ & $\begin{array}{l}\text { The development of personal environmental literacy is from low to high, step by step, } \\
\text { and can be developed through three levels: nominal, functional, and operational. }\end{array}$ \\
\hline 1999 & Wang Min & $\begin{array}{l}\text { Environmental literacy can be synonymous with environmental awareness. } \\
\text { Environmental awareness is a multilevel, all-encompassing content system covering the } \\
\text { relationship between people and the environment. Its purpose is to promote the } \\
\text { coordination of human and environmental relations from multiple sides and multiple } \\
\text { levels. It is a comprehensive theoretical overview of human relations between people } \\
\text { and the environment. }\end{array}$ \\
\hline 2010 & $\begin{array}{l}\text { Research Project Group of the } \\
\text { Research Project on National } \\
\text { Public Environmental Literacy } \\
\text { Indicator System }\end{array}$ & $\begin{array}{l}\text { Environmental literacy refers to knowledge, values, and action systems concerning the } \\
\text { environment and the relationship between humans and the environment, which is } \\
\text { gradually formed by people through the information provided by daily life, learning, } \\
\text { and media communication. }\end{array}$ \\
\hline
\end{tabular}

Personal environmental literacy can significantly influence environmental behavior and promote the emergence of their environmental behavior [23]. Taeshina [24] explored the impact of environmental literacy on farmers' farmland ecological protection behavior and concluded that farmers' environmental skills had the greatest impact on ecological protection behavior. As an important part of environmental literacy, environmental awareness can make individuals pay attention to the environment and accept related information, correctly understand and evaluate environmental problems, and consciously regulate their own behavior. That is, people with stronger natural consciousness have more environmental behaviors [25].

The evaluation of citizens' environmental literacy can understand the characteristics of citizens' environmental literacy and their support for environmental behavior. In 1976, the Department of Environmental Education of South Carolina developed a preliminary evaluation index system of environmental literacy, which includes knowledge, skills, and attitudes [26]. The research group of "the research project on Chinese public environmental literacy indicator system" divides environmental literacy into four aspects: environmental knowledge, environmental values, environmental attitude, and environmental behavior. Up to now, most environmental literacy assessments have been carried out on the basis of environmental knowledge, environmental attitude, and environmental behavior. Based on this, this paper designs an environmental literacy measurement scale including three dimensions of environmental knowledge, environmental values, and environmental behavior.

Environmental knowledge is the foundation of environmental literacy [27]. On the composition of environmental knowledge, different scholars put forward different opinions. According to the different levels of environmental issues citizens are involved in, it can be divided into daily life, regional, and global environmental knowledge [28]. Sun's article [29] divides environmental knowledge into the knowledge of environmental problems and knowledge and skills of adopting environmental behaviors. Chen and Lou [30] believes that environmental knowledge includes knowledge understanding degree and knowledge approach. For the design of measurement items of environmental knowledge dimensions, we can use the combination of knowledge rate and accuracy rate, the Likert scale and single choice. In terms of environmental knowledge scale, the Chinese General Social Survey project (CGSS2010), which is hosted by the Department of Sociology of Renmin University of China and jointly implemented by other academic units, has formed a more authoritative environmental knowledge scale [31] by verifying a large number of people in various provinces and cities in China. 
Environmental values are important standards and norms for people to deal with the relationship between humans and the ecological environment, and their evaluation development is the most mature. Among them, the most famous and influential measurement scale is the "new ecological paradigm" (NEP) scale. This scale was proposed by Dunlap and Van Liere, and its applicability in China has been extensively tested. Hong [32] concluded that the properly revised NEP scale can be used as an important tool to measure public concern about the environment. Yao [33] took haze in Shanxi province as a microcosm of China's experience and concluded that the NEP has a strong explanatory power for the microcosm. Wu and Zhu's paper [34] showed that the revised student version of the NEP scale had good reliability.

There are many different expressions of environmental behavior, such as environmentally friendly, pro-environmental, ecological, environmental protection, and sustainable behavior. The connotations expressed are basically the same, emphasizing the individual's active participation and action to solve or prevent ecological environmental problems. The environmental behavior reflects the behavior subject's respect for nature, is conducive to human survival and the development of positive pro-social behavior. In terms of the composition of environmental behavior, Hines and Hungerford [20] divided environmental behavior into five categories: ecological management, persuasion, consumption, political behavior, and legal behavior. Stern [35] proposed the concept of environmentally significant behaviors, which can be divided into four categories, including the environmental protection behavior of individual citizens, such as limiting automobile exhaust emissions and domestic water use, which are closely related to the daily life of the individual. Based on this, this paper carries out measurement from the dimension of daily environmental behavior and behavior frequency, such as clothing, food, housing, and transportation.

\subsection{Environmental Education}

Pritchard initially proposed the concept of environmental education in the establishment of the International Union for Protection of Nature and Natural Resources (IUPN) in 1948. Currently, there are three theories about the connotation of environmental education: discipline theory, process theory, and method theory (see Table 2) [36]. Due to changes to, and the expansion of the concept, there is still a lack of complete consensus on the definition of environmental education. However, it is widely accepted that environmental education is aimed at protecting the environment and promoting the consciousness and behavior of environmental protection by cultivating or improving people's related knowledge, skills, attitudes, and values. In addition, previous research conducted by numerous scholars in various fields has proven that environmental education can enhance public environmental literacy and promote environmental protection behaviors [37].

In the 21st century, the concept of sustainable development has been gradually attracting attention from all walks of life. The United Nations Conference on Environment and Development (UNCED) adopted Agenda 21, which pointed out the importance of environmental education to enhance the abilities of solving environmental problems, and also added the idea of "sustainable development" as the new connotation and target of environmental education [38].

In conclusion, citizens who receive environmental education will grasp a stronger awareness of environment, more skills of environmental protection, deeper consciousness of the relationship between humans and nature, thus joining in protecting the environment to promote sustainable urban development. 
Table 2. Classical definitions of three theories of environmental education [39-41].

\begin{tabular}{|c|c|c|}
\hline Theory & Connotation of Theory & Classical Definition \\
\hline $\begin{array}{l}\text { Discipline } \\
\text { theory }\end{array}$ & $\begin{array}{l}\text { Regards environmental education } \\
\text { as an educational subject from the } \\
\text { perspective of subject attributes }\end{array}$ & $\begin{array}{l}\text { "Environmental education is an interdisciplinary course in the field of } \\
\text { education, whose purpose is directly pointed to problem-solving and the } \\
\text { realization of the local environment. It involves all forms of educational } \\
\text { processes in general and professional, in school and out of school". (Tbilisi } \\
\text { Conference, 1977) }\end{array}$ \\
\hline Process theory & $\begin{array}{l}\text { Regards environmental education } \\
\text { as a way to realize its value }\end{array}$ & $\begin{array}{l}\text { Environmental education is to cultivate people's clear consciousness of and } \\
\text { attention to the mutual relationship between economy, society, politics, } \\
\text { and ecology in urban and rural areas, to provide everyone with all } \\
\text { opportunities for necessary knowledge, values, attitudes, obligations, } \\
\text { and skills to protect and improve the environment, and to create new patterns } \\
\text { of behavior of individual groups and society as a whole toward the } \\
\text { environment. (Charter of Belgrade, the Global Framework for Environmental } \\
\text { Education) }\end{array}$ \\
\hline Method theory & $\begin{array}{l}\text { Regards environmental education } \\
\text { as a method or purpose to obtain } \\
\text { environmental knowledge }\end{array}$ & $\begin{array}{l}\text { Usually, environmental education is the process of understanding values and } \\
\text { clarifying concepts and establishes the attitudes and skills that people must } \\
\text { know and master in the relationship between people, affiliated culture, } \\
\text { and the biophysical environment. In the decision-making and normative } \\
\text { self-form of environmental quality issues, environmental education } \\
\text { undertakes the task of practice. (International Union for Protection of Nature } \\
\text { and Natural Resources, 1970) }\end{array}$ \\
\hline
\end{tabular}

\subsection{Study on the Environmental Education Demand}

This study first introduces the concept of demand before that of environment education demand. The concept of demand often appears in the fields of economics and psychology. In economics, demand refers to the consumer's need for purchasing certain goods under a certain period of time and under certain price conditions; while in psychology, demand refers to a certain lack or imbalance in the organism, and it is mostly expressed in the form of intention, desire, motivation, interest and values in human activities [42]. For example, in [43], the psychologist Kurt Lewin pointed out a certain balance between the individual and the environment. If that balance was damaged, the individual would generate tension, then the demand and motivation to ease nervousness would be stimulated. So, compared with psychology, the demand in economics is also affected by external factors, such as the ability to pay, supply, and other factors. Inspired by the concept of "demand" in psychology, this paper believes that the demand for environmental education is the demand of mankind to learn about environmental knowledge and environmental skills in order to achieve a balance between man and nature and to eliminate the adverse effects of environmental problems.

Public environmental education systems consist of environmental education content and environmental education methods. The environmental education content corresponds to different educational objects in different scenes, and the content composition is different. The content of environmental education for students in schools includes environmental knowledge and ethics. In tourism activities, the content for tourists includes environmental ethics, attitudes, management technology, and knowledge [44]. In communities, the content for residents includes environmental knowledge, skills, behaviors, and emotions [45]. It can be concluded from the above studies that the contents of public environmental education include environmental knowledge, environmental skills, and environmental ethics according to the public's cognition of the environment. Environmental knowledge is supposed to help people understand the objective matters and general laws of nature. Environmental skills can help people to develop behaviors of protection. Environmental ethics is to help people understand and think about the relationship between man and nature. With the development of information technology, environmental education has become more abundant. The traditional methods of environmental education mainly include school and non-school education. School environmental education is the main form of implementation in the international community at present [46], which is mainly aimed at school students, such as the Green Ribbon Schools program in the United States and the Youth Regional Environment Program in Japan [47]. Non-school education is represented by environmental education for the public in specific places of rural, natural, and outdoor education [48]. With social networks and the use of mobile media subverting and substituting for the traditional ways 
of disseminating information, the methods and channels of environmental education are also constantly changing. The purpose of this paper is to promote environmental education for the public in Beijing, considering that there are many types of audience and various channels for receiving information, so the research on the mode of environmental education is mainly based on the study of mass media [49].

The subsequent study on reasons for individuals' different environmental education demand shows that individuals have different environmental education demands due to various factors, such as sociodemographic characteristics and environmental education experiences [50]. At present, there are few studies on the factors of public environmental education demands. So, this study conducts a literature review of the influential factors about the demand for education, which is the superior concept of environmental education. The relevant literature indicates that there are mainly three types of factors affecting the demand for education: economic factors, cultural factors, and social factors $[51,52]$. The impact of economic factors on education demand is that the better the family or individual's material conditions, the higher the individual's need for higher-level teaching. The impact of cultural factors is that when the family or individual receives more and better education, the deeper their knowledge of education, the more they can recognize the benefits brought by education, and the higher their demand for education. The impact of social factors is that, with the complete educational resources that society can provide, like settings, teachers, etc., the education demand of an individual will increase a lot. Accordingly, the environmental education demand discussed in this study excludes environmental factors from the perspective of psychology. Therefore, this study mainly discusses the influence of cultural factors on the demand for environmental education. From the influence of cultural factors on education demand, it can be inferred that the higher the individual's cognitive level of environmental knowledge, environmental protection skills, and the relationship between people and the environment, the higher their demand for environmental education will be. For example, Zhang Qi conducted a survey on the green lifestyle of Beijing residents and found that citizens who had a high level of awareness and practice of green lifestyles were willing to learn more about green lifestyles [53].

In summary, the public's awareness of environmental knowledge and environmental skills affects their demand for environmental education. Therefore, before conducting a survey on the environmental education demand of the public, it is necessary to understand their current status of environmental knowledge, environmental skills, and environmental ethics, that is, to evaluate their level of environmental literacy first.

\section{Materials and Methods}

According to the research purpose, this study used the method of questionnaire to investigate the level of environmental literacy and environmental education needs of citizens. The study was carried out in several steps. First, we developed a draft questionnaire based on related literature and adjusted the questionnaire through pre-survey to improve the validity of the questionnaire. Second, we delivered the questionnaire to Beijing citizens for data collection. Finally, we analyzed the data and discussed the results by SPSS. The analysis includes an evaluation of the environmental literacy of Beijing residents, and the differences in environmental education needs of samples with different levels of environmental literacy.

\subsection{Questionnaire Design}

We developed the questionnaire following a literature review. Before the formal survey, we conducted a pre-survey to adjust the expression of the items in the questionnaire, so that the respondents can understand it more easily, and then we got the final questionnaire.

The questionnaire comprised 3 parts $(\mathrm{A}-\mathrm{C})$.

Part A was a survey of environmental literacy, which incorporated 29 items on environmental values, knowledge, and behavior. Each item was assigned a score of $1-5$, with 1 being the lowest and 5 the highest. The Chinese New Environmental Paradigm (CNEP) scale was directly used as the scale 
of environmental values in this study. The CNEP scale [52] originated from the 2000 version of the New Environmental Paradigm (NEP) scale, which was obtained after a nationwide test, and then added to the Chinese General Social Survey Project and applied to the nationwide survey [53]. The scale of environmental knowledge was designed with reference to the Chinese General Social Survey (CGSS2010) and adjusted according to the actual situation in Beijing. The environmental behavior scale was set based on people's daily environmental behaviors, such as clothing, food, housing, transportation, etc. These 29 items were measured on a five-point Likert scale, ranging from 1 (extremely disagree) to 5 (extremely agree). Respondents were asked to choose the most suitable number according to their own situations.

Part B was a survey of environmental education needs preferences, including questions on citizens' environmental education content and media preferences. The content of environmental education includes 6 dimensions: the knowledge of urban environmental background, the knowledge of environmental factors, the knowledge of ecological science, environmental protection knowledge and skills, green lifestyle, and ecological ethics [54]. The survey of environmental education content preferences was composed of 21 items, and each item was also measured on a 5-point Likert scale. The media of environmental education includes mass media channels such as Wechat, TV, newspapers and so on; the place of environment education such as outdoors, community, museum and so on; the way of environment education such as staff commentary, video teaching and so on. Respondents were asked to check the given options.

Part $C$ was a survey of social demographic characteristics, including the respondents' gender, age, education, occupation, monthly income, and length of residence in Beijing.

\subsection{Data Collection}

We tested the questionnaire through a pre-survey to ensure that participants could understand the description of each item and provide a true answer. Considering that education background and age are the main factors affecting people's understanding ability, the pre-survey was conducted in Beijing Olympic Forest Park. The sample involved citizens of diverse ages and educational backgrounds, and 26 citizens took part in the survey. The questionnaire was modified according to the questions citizens asked about its content and language descriptions during the survey.

The official survey was conducted in 4 urban public spaces in Beijing in September 2019, including residential areas, natural parks, commercial complexes, and commercial office areas [55,56]. A total of 435 individuals returned completed questionnaires, among which 383 were considered valid for our analysis, with an effective rate of $88 \%$.

\subsection{Data Analysis}

We used SPSS Statistics version 25 (IBM Corp, BJ, CHN) to analyze the data.

\subsubsection{Reliability and Validity Test}

We began with reliability and validity testing. Cronbach's $\alpha$ was used to test the reliability of the environmental literacy scale, the content of environment education scale, as well as the entire questionnaire. When the value of Cronbach's $\alpha$ is higher than 0.7 , the factor being analyzed is regarded to be of high reliability. As shown in Table 3, the data of this study are reliable. In addition, based on the previous literature review, the scale used in this study has been tested by many scholars, which provides strong support for the validity of this scale. Besides, the pre-survey also contributes to the validity of the questionnaire. 
Table 3. Survey reliability test results.

\begin{tabular}{ccc}
\hline & ${ }^{\text {a }}$ Cronbach's Alpha & Items \\
\hline Questionnaire & 0.858 & 103 \\
\hline Environmental Literacy & 0.708 & 29 \\
\hline Environmental Education Content & 0.947 & 21 \\
\cline { 2 - 3 } & a Cronbach's alpha values greater than 0.7 means that the questionnaire data are very reliable.
\end{tabular}

\subsubsection{Summarization of Demographic Statistics}

The analysis of the demographic characteristics of the participants found that the sample of this study is representative of the need to study the environmental education of Beijing citizens. The gender distribution among the participants was $43.3 \%$ men and $56.7 \%$ women. The results of age and education are the same as the trend of the Beijing Municipal Bureau of Statistics for the Sixth National Population Census in 2010 [57]. The survey results on income are the same as the 2019 Beijing Salary Level Report published by Baidu [58], and 70\% of the participants had an income below 142 USD. Participants $19-30$ years of age accounted for $58.3 \%$.

\section{Evaluation of Environmental Literacy of Beijing Citizens}

\subsection{General Evaluation of Citizens' Environmental Literacy}

The evaluation of citizens' environmental literacy consisted of three parts: environmental behavior, environmental knowledge, and environmental values, which involved 29 indices with a positive score of 1 (lowest) to 5 (highest).

Through mean analysis, it can be found that the score of the environmental behavior dimension is the highest $(\mathrm{M}=4.04)$, and the means of environmental values $(\mathrm{M}=3.74)$ and environmental knowledge $(M=3.48)$ are lower than that of overall environmental literacy $(M=3.77)$ (see Table 4$)$. It can be argued that there is still much room for improvement in the environmental literacy of Beijing citizens, especially in the values and the knowledge dimensions, which explains the need for environmental education.

Table 4. Average score of Beijing citizens' environmental literacy (five is highest and one is lowest).

\begin{tabular}{ccccc}
\hline & $\begin{array}{c}\text { Average Score of } \\
\text { Environmental Behavior }\end{array}$ & $\begin{array}{c}\text { Average Score of } \\
\text { Environmental Knowledge }\end{array}$ & $\begin{array}{c}\text { Average Score of } \\
\text { Environmental Values }\end{array}$ & $\begin{array}{c}\text { Average Score of } \\
\text { Environmental Literacy }\end{array}$ \\
\hline Average value & 4.0413 & 3.4794 & 3.7423 & 3.7740 \\
Standard deviation & 0.50730 & 0.79234 & 0.43461 & 0.38350 \\
\hline
\end{tabular}

\subsection{Environmental Literacy Levels of Survey Respondents}

A total of 29 indices were involved in the environmental literacy assessment scale. The total score of environmental literacy was 145 by assigning a positive score of one to five to each index. The environmental literacy assessment scores of 383 survey participants were counted, and the minimum, lower quartile, median, upper quartile, and maximum values were obtained. Based on the data of these five groups, 383 participants were divided into three groups according to the score of environmental literacy assessment: high score, moderate score, and low score (see Table 5). In addition, from Table 6, significance was less than 0.05 , passing the test, so it can be seen that the grouping method has strong reliability. 
Table 5. Descriptive statistics of groups for the environmental literacy of citizens.

\begin{tabular}{ccccc}
\hline Group & Frequency & Percentage & Effective Percentage & Cumulative Perception \\
\hline Low score & 85 & 22.2 & 22.2 & 22.2 \\
Middle score & 206 & 53.8 & 53.8 & 76.0 \\
High score & 92 & 24.0 & 24.0 & 100.0 \\
Total & 383 & 100.0 & 100.0 & \\
\hline
\end{tabular}

Table 6. Variance analysis of environmental literacy score of participants.

\begin{tabular}{cccccc}
\hline & Quadratic Sum & Variance & Mean Square & F & Significance \\
\hline Among the group & $33,716.668$ & 2 & 16858.334 & 620.159 & 0.000 \\
Within the group & $10,329.880$ & 380 & 27.184 & & \\
Total & $44,046.548$ & 382 & & & \\
\hline
\end{tabular}

In order to effectively locate the group of environmental education service, the sociodemographic characteristics of the three groups with low scores in senior high school were analyzed. Among them, there was a significant correlation between gender, educational background, age, length of residence, and occupation and the environmental literacy evaluation score. There was no significant correlation between income and environmental literacy evaluation score.

The proportion of women in the group with high and moderate environmental literacy scores was much higher than that of men, and the proportion of men in the group with low environmental literacy scores was significantly higher than that of women (see Table 7).

In general, the higher the individual's education, the higher their environmental literacy evaluation score. Compared with the overall sample, the proportion of citizens with a master's degree or above was higher in the high and middle groups. The proportion of people with low environmental literacy in primary and secondary schools and below was significantly higher than that of the total. There was not much difference in the proportion of respondents with junior high school, senior high school, a college education, and undergraduates in the high- and low-scoring groups (see Table 8).

In general, the older the individual, the higher their environmental literacy evaluation score. It is worth noting that 24-years old was the turning point of environmental literacy assessment (see Table 9). The low and middle environmental literacy groups of 19-24-year-olds accounted for the highest proportion, and 25-40-year-olds in the high environmental literacy assessment group accounted for a higher proportion.

In general, the longer people live, the higher their evaluation of environmental literacy will be. Among the high evaluation groups, residence for more than 10 years accounted for a higher percentage, and in the middle and low groups, residence for less than four years accounted for a higher percentage (see Table 10). However, the proportion of those with 5-9 years of residence in the three groups was basically the same. This conclusion can be explained by the theory of place attachment. The longer residents stay in a place, the more positive their emotions, cognition, and behavior will be $[59,60]$.

There are obvious differences in the occupations of participants in the three groups of environmental literacy evaluation. Among the high-scoring group, four occupations (government staff, public institutions staff, housewives, and retirees) accounted for a higher proportion. Among the middle-scoring group, the proportion of three occupations (public institutions staff, company managers, and students) was obviously higher. In the low-scoring group, the proportion of employees was obviously higher. 
Table 7. Cross-analysis of environmental literacy evaluation groups and gender.

\begin{tabular}{|c|c|c|c|c|c|c|}
\hline & Low Score Group & Middle Score Group & High Score Group & Total & Pearson Square & Progressive Significance (Bilateral) \\
\hline Male & $56.5 \%$ & $39.8 \%$ & $39.1 \%$ & $43.3 \%$ & \multirow{4}{*}{$39.610^{a}$} & \multirow{4}{*}{$\begin{array}{c}0.002 \\
(p<0.05, \text { indicates significant correlation })\end{array}$} \\
\hline Female & $43.5 \%$ & $60.2 \%$ & $60.9 \%$ & $56.7 \%$ & & \\
\hline Count & 85 & 206 & 92 & 383 & & \\
\hline Total & $100.0 \%$ & $100.0 \%$ & $100.0 \%$ & $100.0 \%$ & & \\
\hline
\end{tabular}

Table 8. Cross-analysis of environmental literacy evaluation and qualifications.

\begin{tabular}{|c|c|c|c|c|c|c|}
\hline & Low-Scoring Group & Middle-Scoring Group & High-Scoring Group & Total & Pearson Square & Progressive Significance (Bilateral) \\
\hline Primary school and below & $4.7 \%$ & $0.5 \%$ & $1.1 \%$ & $1.6 \%$ & & \\
\hline Middle school & $2.4 \%$ & $2.9 \%$ & $3.3 \%$ & $2.9 \%$ & & \\
\hline High school and college & $20.0 \%$ & $10.2 \%$ & $16.3 \%$ & $13.8 \%$ & & \\
\hline Undergraduate & $55.3 \%$ & $49.5 \%$ & $43.5 \%$ & $49.3 \%$ & $20.455^{\mathrm{a}}$ & 0.009 \\
\hline Master's degree and above & $17.6 \%$ & $36.9 \%$ & $35.9 \%$ & $32.4 \%$ & & \\
\hline Count & 85 & 206 & 92 & 383 & & \\
\hline Total & $100.0 \%$ & $100.0 \%$ & $100.0 \%$ & $100.0 \%$ & & \\
\hline
\end{tabular}

${ }^{a}$ the Pearson Square is the sum of squares divided by the degrees of freedom.

Table 9. Cross-analysis of environmental literacy evaluation and ages.

\begin{tabular}{ccccccc}
\hline & Low-Scoring Group & Middle-Scoring Group & High-Scoring Group & Total & F & Significance \\
\hline Under 18 & $2.4 \%$ & $1.5 \%$ & $2.2 \%$ & $1.8 \%$ & & \\
$19-24$ years & $36.5 \%$ & $37.9 \%$ & $16.3 \%$ & $32.4 \%$ & \\
$25-30$ years & $28.2 \%$ & $24.8 \%$ & $26.1 \%$ & $25.8 \%$ & \\
$31-40$ years & $20.0 \%$ & $21.8 \%$ & $31.5 \%$ & $23.8 \%$ & 7.839 & 0.000 \\
$41-50$ years & $9.4 \%$ & $9.7 \%$ & $14.1 \%$ & $10.7 \%$ & \\
$51-60$ years & $2.4 \%$ & $1.5 \%$ & $3.3 \%$ & $2.1 \%$ & \\
Over 61 & $1.2 \%$ & $2.9 \%$ & $6.5 \%$ & $3.4 \%$ & \\
Count & 85 & 206 & 92 & 383 & \\
Total & $100 \%$ & $100.0 \%$ & $100.0 \%$ & $100.0 \%$ & \\
\hline
\end{tabular}


Table 10. Cross-analysis of environmental literacy evaluation and length of residence.

\begin{tabular}{|c|c|c|c|c|c|c|}
\hline & Low-Scoring Group & Middle-Scoring Group & High-Scoring Group & Total & $\mathbf{F}$ & Significance \\
\hline Less than 1 year & $17.6 \%$ & $18.0 \%$ & $7.6 \%$ & $15.4 \%$ & & \\
\hline 2-4 years & $28.2 \%$ & $27.2 \%$ & $16.3 \%$ & $24.8 \%$ & & \\
\hline 5-9 years & $24.7 \%$ & $20.9 \%$ & $23.9 \%$ & $22.5 \%$ & & \\
\hline More than 10 years & $12.9 \%$ & $19.9 \%$ & $22.8 \%$ & $18.8 \%$ & 7.723 & 0.001 \\
\hline Local people & $16.5 \%$ & $14.1 \%$ & $29.3 \%$ & $18.3 \%$ & & \\
\hline Count & 85 & 206 & 92 & 383 & & \\
\hline Total & $100.0 \%$ & $100.0 \%$ & $100.0 \%$ & $100.0 \%$ & & \\
\hline
\end{tabular}




\section{Environmental Literacy Groups' Preference for Environmental Education}

\subsection{Preferences of Environmental Literacy Groups for Environmental Education Content}

Figure 1 shows the preferences of the overall sample and the high, medium, and low groups for environmental education content. Compared with the preference degree of the overall sample for different environmental education contents, it can be seen that the high group has a higher preference for all environmental education content. The medium group is basically the same as the overall sample and is only slightly lower than the overall level in terms of the knowledge of environmental factors. The low group has a lower preference for all environmental education contents and the lowest preference for the knowledge of environmental background.

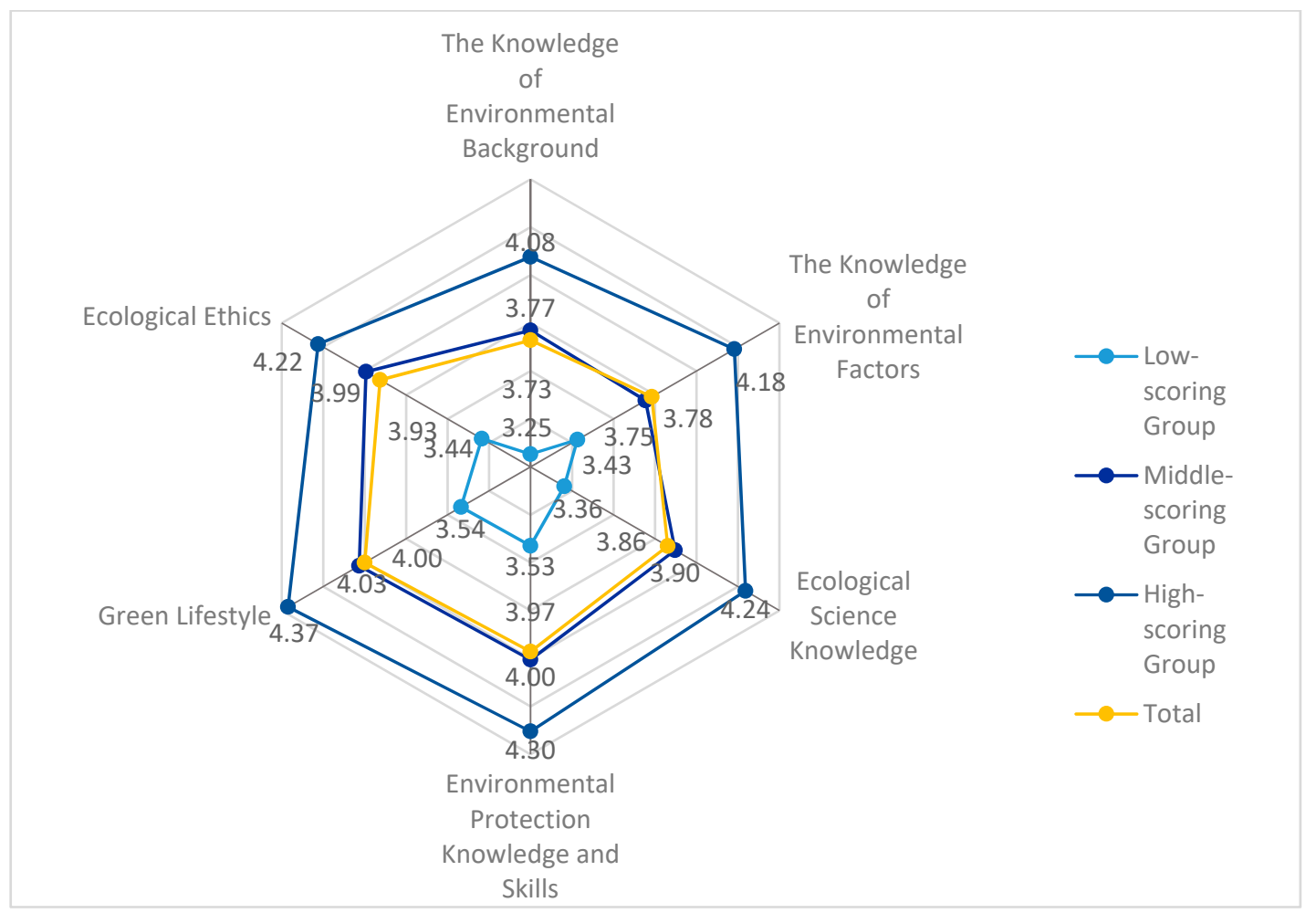

Figure 1. Degrees of preference for environmental education content.

As for the preference for environmental education content, the preference degree of participants in the high-scoring group for "green lifestyle", "environmental protection knowledge and skills", and "ecological science knowledge" was greater than the mean value of the overall preference for environmental education content $(\mathrm{M}=4.23)$ (see Figure $2 \mathrm{a})$. The preference degree of participants in the medium-scoring group for "green lifestyle", "environmental protection knowledge and skills", and "ecological science knowledge" was greater than the mean value of the overall preference for environmental education content $(\mathrm{M}=3.91)$ (see Figure $2 \mathrm{~b}$ ). The preference degree of participants in the lower scoring group for "green lifestyle", "environmental protection knowledge and skills", "environmental ethics", and "the knowledge of environmental factors" was greater than the mean value of the overall preference for environmental education content $(\mathrm{M}=3.43)$ (see Figure $2 \mathrm{c}$ ).

By comparing the three groups' preferences for environmental education content, it can be seen that "green lifestyle" and "environmental protection knowledge" are what Beijing citizens want to know and learn. Existing studies have shown that "most of what adults learn is practical and skill-based" [61], and "green lifestyle" and "protective knowledge" are more closely related to peoples daily lives than other contents, so they are expected to be understood and learned by everyone. 
It can be seen that participants in the high and middle groups have a higher preference for "ecological science knowledge", while those in the low group have a higher preference for "the knowledge of environmental factors" and "environmental ethics". It can be seen that participants in the higher group prefer to learn systematic knowledge more than those in the lower group. This is reflected by those in the higher group preferring to learn "ecological science knowledge", including ecological systems and processes, while those in the lower group prefer to learn "environmental factor knowledge", including animals, plants, geology, and landforms. This situation may be explained by the theory of developmental psychology. People who are older and have more social roles are able to deal with problems with more systematic thinking when facing complex and diverse social environments [62-64]. Therefore, participants in the high-scoring group with rich social experience have developed the habit of dealing with problems in a more systematic and comprehensive way [65]. Therefore, this group tends to prefer the "ecological science knowledge" category of environmental education. Most of the participants in the lower group are students and young people who have just entered society (in China, teenagers and young people are less independent $[66,67]$ ), with less economic pressure and family responsibility, they have rich imagination and creativity, and hope to change the world [68]. Therefore, young people are more eager and energetic to pay attention to the "environmental ethics", such as international environmental issues and human-natural relations that have little to do with real life.

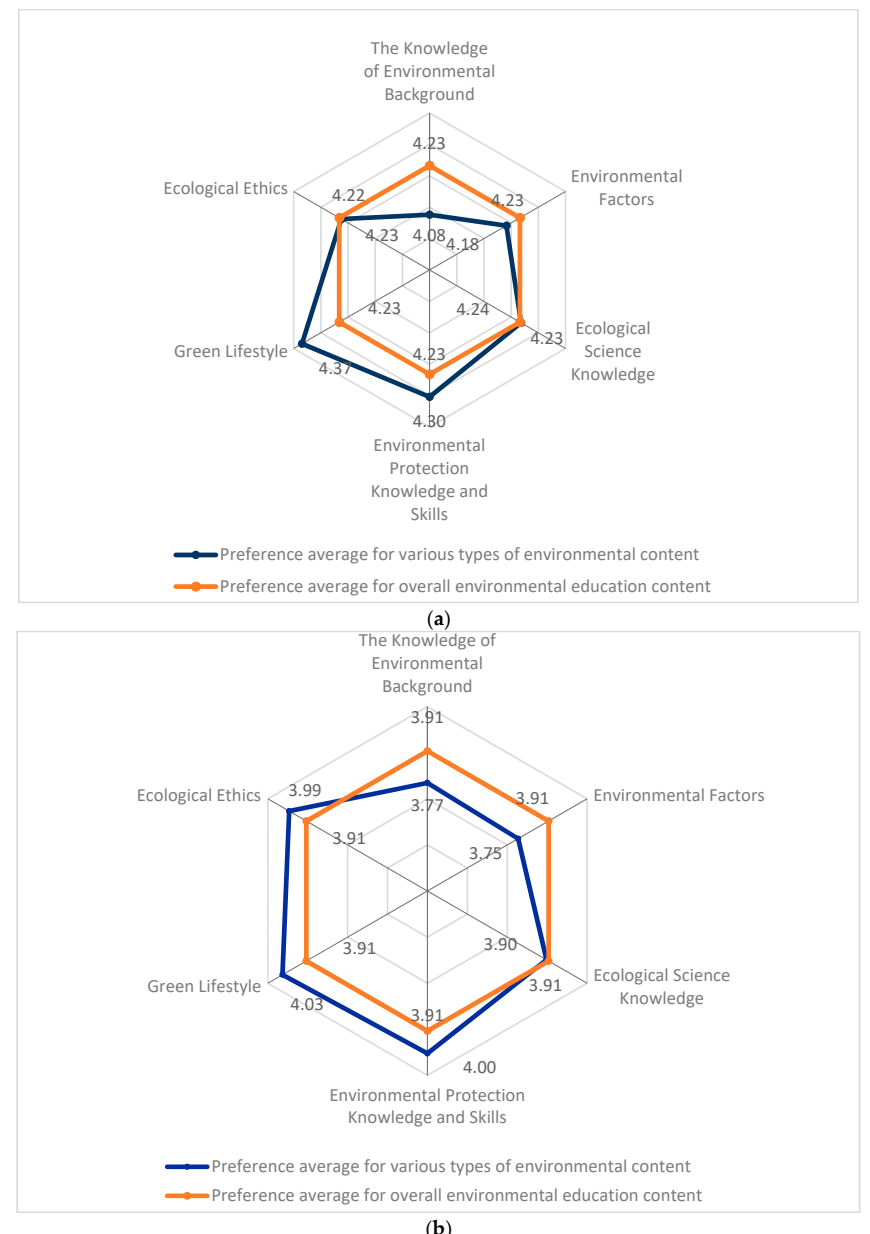

(b)

Figure 2. Cont. 


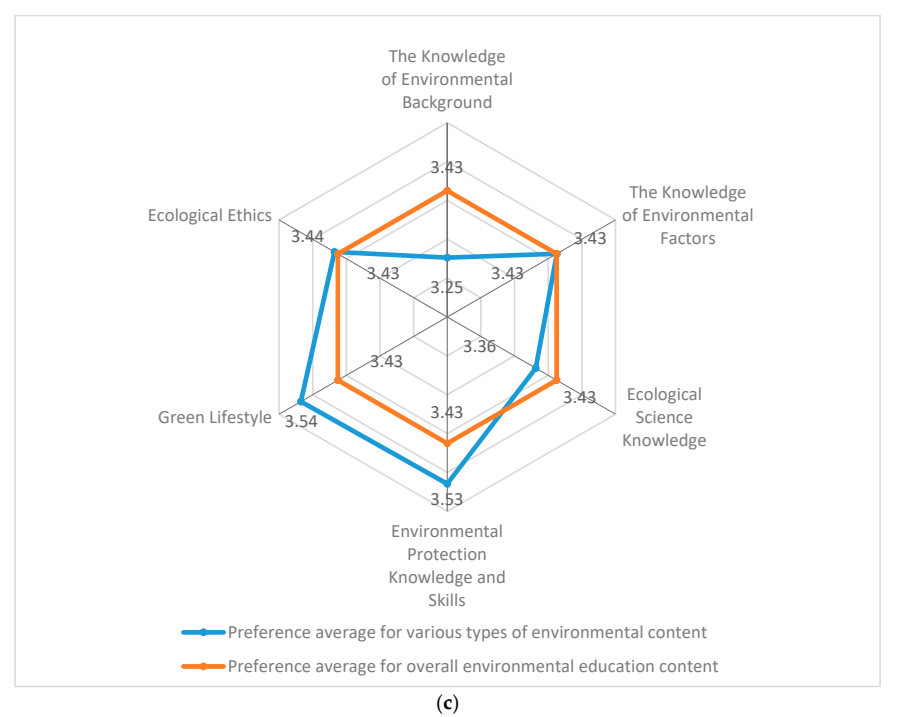

Figure 2. Groups have preferences for different environmental education contents: (a) high-scoring groups; (b) middle-scoring groups; (c) lower scoring groups.

\subsection{Environmental Education Activity Place Preference}

The environmental education activity place preference survey mainly includes four types: lectures, exhibition venues and forms (museums, educational centers, experience halls, special exhibitions, etc.), community activities, and outdoor leisure spaces and activities. The participants were allowed to select more than one option in this survey.

As indicated in Table 11, on the whole, participants had the highest preference for outdoor leisure space and activities, followed by exhibition venues and activity forms ( $54.6 \%)$, wheras lectures and community activities received the lowest preference (21.4\% and $18.3 \%$, respectively).

The chi-square test in Tables 12 and 13 show significant differences between groups of environmental literacy evaluation scores and types of lecture and exhibition venues ( $p$ value is 0.003 and 0.001 , respectively, much lower than 0.05 ). The preference of the high environmental literacy group for lecture activities (31.5\%) and exhibition activities (62\%) was significantly higher than the overall preference level (overall sample preference for lectures and exhibition activities was $21.4 \%$ and $54.6 \%$, respectively).

In terms of educational media in environmental education activity places, there were five options: text interpretation facilities, video interpretation facilities, portable electronic voice interpretation equipment, artificial interpretation, and handbooks. In this survey, participants had multiple choices.

Table 14 demonstrates that in general, the participants had the highest preference for artificial interpretation (47.8\%) and video interpretation (43.6\%) facilities, followed by handbooks $(33.4 \%)$, text interpretation facilities $(20.1 \%)$, and portable electronic voice interpretation equipment $(23.2 \%)$.

The chi-square test in Table 15 shows a significant difference in the preferences of the different groups for user handbooks ( $p=0.002$, much less than 0.05 ). The high-scoring group had a higher preference for handbooks.

In addition, in this survey, participants repeatedly proposed the use of advanced technologies, e.g., virtual reality (VR). 
Table 11. Cross-analysis of environmental literacy groups and environmental education activity types.

\begin{tabular}{|c|c|c|c|c|c|}
\hline & Measurement & Low-Scoring Group & Middle-Scoring Group & High-Scoring Group & Total \\
\hline \multirow{2}{*}{ Lecture activities } & Count & 9 & 44 & 29 & 82 \\
\hline & Percentage & $10.6 \%$ & $21.4 \%$ & $31.5 \%$ & $21.4 \%$ \\
\hline \multirow{2}{*}{ Exhibition venues and activities } & Count & 31 & 121 & 57 & 209 \\
\hline & Percentage & $36.5 \%$ & $58.7 \%$ & $62.0 \%$ & $54.6 \%$ \\
\hline \multirow{2}{*}{ Community activities } & Count & 13 & 34 & 23 & 70 \\
\hline & Percentage & $15.3 \%$ & $16.5 \%$ & $25.0 \%$ & $18.3 \%$ \\
\hline \multirow{2}{*}{ Outdoor leisure space and activities } & Count & 60 & 148 & 64 & 272 \\
\hline & Percentage & $70.6 \%$ & $71.8 \%$ & $69.6 \%$ & $71.0 \%$ \\
\hline \multirow{2}{*}{ Total } & Count & 85 & 206 & 92 & 383 \\
\hline & Percentage & $100.0 \%$ & $100.0 \%$ & $100.0 \%$ & $100.0 \%$ \\
\hline
\end{tabular}

Table 12. Chi-square test of groups of environmental literacy evaluation scores and lecture activities.

\begin{tabular}{cccc}
\hline & Value & Degrees of Freedom & Progressive Saliency (Both Sides) \\
\hline Pearson chi-square & $11.507^{\text {a }}$ & 2 & 0.003 \\
Likelihood ratio & 12.017 & 2 & 0.002 \\
Linear correlation & 11.472 & 1 & 0.001 \\
Number of valid cases & 383 & & \\
\hline
\end{tabular}

${ }^{\text {a }}$ Expected count of 0 cells $(0.0 \%)$ is less than 5 . Minimum expected count is 18.20 .

Table 13. Chi-square test of groups of environmental literacy evaluation scores and exhibition activities.

\begin{tabular}{cccc}
\hline & Value & Degrees of Freedom & Progressive Saliency (Both Sides) \\
\hline Pearson chi-square & $14.700^{\mathrm{a}}$ & 2 & 0.001 \\
Likelihood ratio & 14.735 & 2 & 0.001 \\
Linear correlation & 11.190 & 1 & 0.001 \\
Number of valid cases & 383 & & \\
\hline
\end{tabular}

a Expected count of 0 cells $(0.0 \%)$ is less than 5 . Minimum expected count is 38.62 . 
Table 14. Cross-analysis of groups of environmental literacy evaluation scores and environmental education activity media types.

\begin{tabular}{|c|c|c|c|c|c|}
\hline & Measurement & Low-Scoring Group & Middle-Scoring Group & High-Scoring Group & Total \\
\hline \multirow{2}{*}{ Text interpretation facilities } & Count & 13 & 42 & 22 & 77 \\
\hline & Percentage & $15.3 \%$ & $20.4 \%$ & $23.9 \%$ & $20.1 \%$ \\
\hline \multirow{2}{*}{ Video interpretation facilities } & Count & 34 & 96 & 37 & 167 \\
\hline & Percentage & $40.0 \%$ & $46.6 \%$ & $40.2 \%$ & $43.6 \%$ \\
\hline \multirow{2}{*}{ Portable electronic voice interpretation equipment } & Count & 12 & 55 & 22 & 89 \\
\hline & Percentage & $14.1 \%$ & $26.7 \%$ & $23.9 \%$ & $23.2 \%$ \\
\hline \multirow{2}{*}{ Artificial interpretation } & Count & 44 & 98 & 41 & 183 \\
\hline & Percentage & $51.8 \%$ & $47.6 \%$ & $44.6 \%$ & $47.8 \%$ \\
\hline \multirow{2}{*}{ Handbooks } & Count & 15 & 80 & 33 & 128 \\
\hline & Percentage & $17.6 \%$ & $38.8 \%$ & $35.9 \%$ & $33.4 \%$ \\
\hline \multirow{2}{*}{ Number of valid cases } & Count & 85 & 206 & 92 & 383 \\
\hline & Percentage & $100.0 \%$ & $100.0 \%$ & $100.0 \%$ & $100.0 \%$ \\
\hline
\end{tabular}

Table 15. Chi-square test of groups of environmental literacy evaluation scores and handbooks.

\begin{tabular}{cccc}
\hline & Value & Degrees of Freedom & Progressive Saliency (Both Sides) \\
\hline Pearson chi-square & $12.466^{\mathrm{a}}$ & 2 & 0.002 \\
Likelihood ratio & 13.503 & 2 & 0.001 \\
The linear correlation & 6.215 & 1 & 0.013 \\
Number of valid cases & 383 & & \\
\hline
\end{tabular}

${ }^{a}$ Expected count of 0 cells $(0.0 \%)$ is less than 5. Minimum expected count is 28.41 . 


\subsection{Preference for Environmental Education Channels}

As discussed in previous sections, nowadays, environmental education is not only for students, but also for the public. Public environmental education through various mass media has been a common practice in all countries in the world. Therefore, it is necessary to investigate the mass media use of Beijing citizens, and it is also important to research how to conduct environmental education through mass media. Based on the behavior characteristics of people using information media, this study divides information media into new and traditional media [69,70]. New media refers to mobile phones and the Internet, which focus on user experiences and feedback, with more personalized content. Traditional media mainly includes, but is not limited to, radio, television, magazines, newspapers, advertisements, and so on. It mainly spreads mainstream social values and has strong publicity.

According to the survey results (see Figure 3), the number of traditional media users is declining, while new media not only has many types of audience, but also a large number of users. The distribution among the participants was as follows: only $12.8 \%$ will watch TV at a fixed time, and $8.9 \%$ will listen to the radio at a fixed time. However, most participants usually use new media, and its use is not limited by time or place. Among the participants, 56\% often use Weibo and WeChat, and $19 \%$ often use forums like Douban, Zhihu, and so on. In addition, $9 \%$ often use short video apps. The survey also found that WeChat Moments, WeChat Subscriptions, and Weibo Hot Search are the most popular when people use new media, indicating that they pay more attention to social value, personal development, and social facts when using new media.

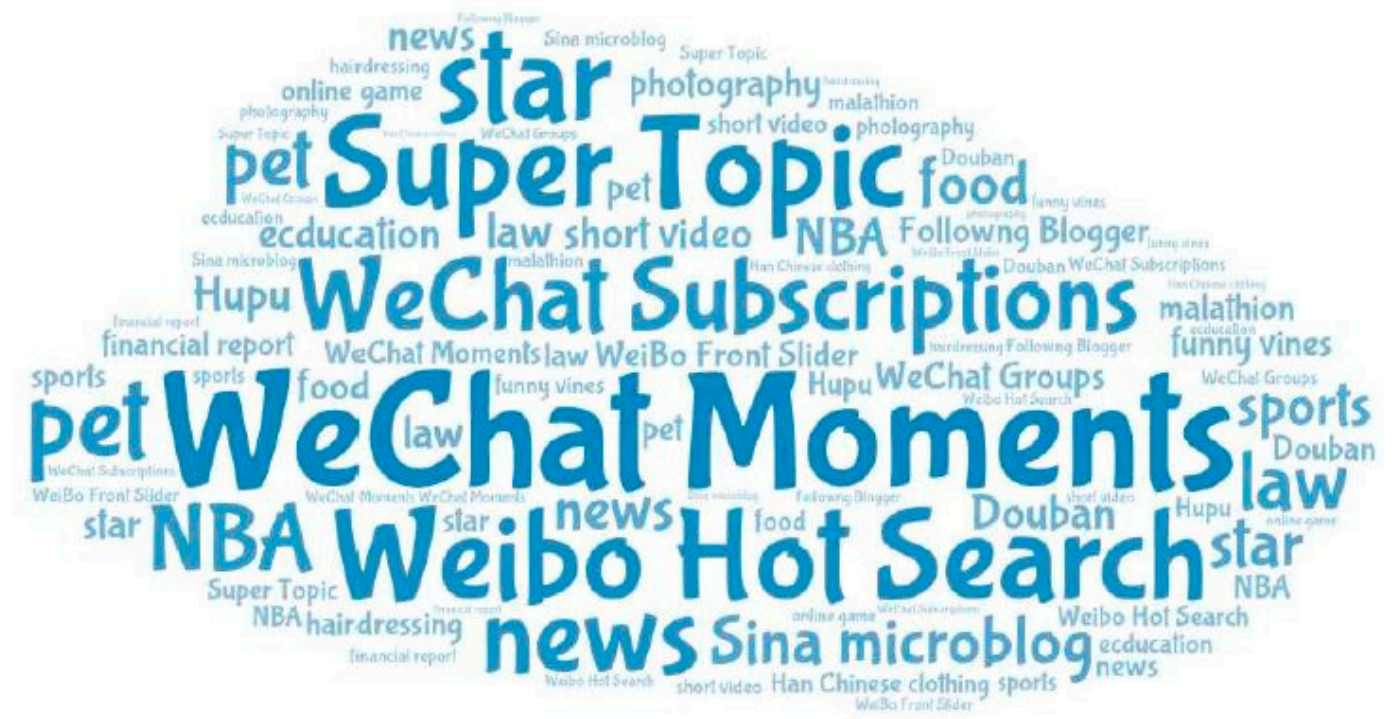

Figure 3. Results of participants' preference for new media.

Regarding the preference for traditional media (see Table 16), 65.3\% chose to watch TV at 15:00-21:00, and they had a higher preference for news (38.8\%) and variety $(42.9 \%)$ programs. The high environmental literacy group showed a higher preference for news $(46.7 \%)$ and variety $(53.3 \%)$ than the overall level. The low group showed a higher preference for competition $(21.4 \%)$ and drama $(35.7 \%)$ than the overall level ( $8.2 \%$ for competition and $28.6 \%$ for drama).

Among the participants, $8.9 \%$ listen to the radio at a fixed time, as $61.8 \%$ listen to the radio from 06:00-09:00, and 20.7\% listen from 17:00-21:00. In general, participants had the highest preference for music (55.9\%) and transportation (41.2\%) programs. In the middle environmental literacy group, the preference for all kinds of programs was higher than the overall level. The high group showed a higher preference for listening to books (41.7\%) than the overall level (29.4\%). 
Advertising is also a kind of media. The types of advertisement most likely to be noticed by participants are pre-film (28.2\%), traffic (27.7\%), outdoor $(27.4 \%)$, and television $(26.4 \%)$ advertisements.

Table 16. Cross-analysis of environmental literacy evaluation groups and TV usage preferences.

\begin{tabular}{cccccc}
\hline Program Type & Measurement & Low-Scoring Group & Middle-Scoring Group & High-Scoring Group & Total \\
\hline \multirow{2}{*}{ News } & Count & 4 & 8 & 7 & 19 \\
& Percentage & $28.6 \%$ & $40.0 \%$ & $46.7 \%$ & $38.8 \%$ \\
\hline \multirow{2}{*}{ Competition } & Count & 3 & 0 & 1 & 4 \\
& Percentage & $21.4 \%$ & $0.0 \%$ & $6.7 \%$ & $8.2 \%$ \\
\hline \multirow{2}{*}{ Variety } & Count & 3 & 10 & 8 & 21 \\
& Percentage & $21.4 \%$ & $50.0 \%$ & $53.3 \%$ & $42.9 \%$ \\
\hline \multirow{2}{*}{ Drama } & Count & 5 & $25.0 \%$ & 4 & 14 \\
& Percentage & $35.7 \%$ & 205 & $26.7 \%$ & $28.6 \%$ \\
\hline \multirow{2}{*}{ Total } & Count & 85 & $53.7 \%$ & $24.1 \%$ & 382 \\
& Percentage & $22.3 \%$ & & & $100.0 \%$ \\
\hline
\end{tabular}

\section{Conclusions and Suggestions}

Through the sampling survey and evaluation of Beijing citizens' environmental literacy, it was found that the average value was 3.77 points, and there is still a considerable amount of room for improvement. The score of environmental behavior literacy was higher than the average value of environmental literacy, while the score of environmental knowledge and environmental values was lower than the average. Thus, it can be seen that it is necessary for Beijing to build a sustainable city and provide environmental education for the public, especially in terms of environmental knowledge and values.

According to the score of environmental literacy evaluation of the survey, the participants were divided into three groups, namely high-, middle-, and low-scoring groups. It was found that the sociodemographic characteristics of the high and middle-scoring groups showed a higher proportion of women and well-educated people. A higher proportion of working or living stability is reflected in the majority of civil servants, staff of public institutions, retirees, and housewives. There were more people over the age of 30, most of whom had resided in Beijing for a long time. The sociodemographic characteristics of the low-scoring group showed that most were men and people with low academic qualifications. Company staff and college students made up the majority and most of them had lived in Beijing for less than five years.

"Green lifestyle" and "knowledge and skills of environmental protection" are the types of environmental education that the participants generally want to learn. In addition, those in the high and middle groups were also more interested in "ecological science knowledge", while the low-scoring group took more interest in "the knowledge of environmental factors" and "environmental ethics".

In terms of the place and mode of environmental education, the preference for environmental education (natural education) was the highest, the preference for exhibition place and activity was second, and the preference for lecture and community activities was relatively low. Regarding the type of educational media, there was a higher preference for the explanation and use of video interpretation facilities, followed by user manuals, while common text interpretation facilities and portable electronic voice equipment were the lowest.

Mass media also constitutes an important channel for environmental education, and the preference for and frequency of using new media such as MicroBlogs, WeChat, and short video applications were much higher than those for traditional media such as TV and newspapers.

The conclusion of this paper can be used as the foundation for more effective environmental education for citizens. For example, this study shows that most people like outdoor environmental education, and other studies showed that the natural environment compared to the urban environment can promote cooperation between humans and nature [71]. Therefore, improving citizens' environmental literacy and accelerating sustainable city construction by building outdoor 
environmental education systems that include interpretive signs, tourist centers, and natural education centers in urban and natural parks is of great significance.

\section{Research Limitations and Prospects}

Although we try to make every link reasonable in the research process, there are still some inevitable limitations. First, we only used the questionnaire survey method in this study, which means the survey of public demand may not be comprehensive. In the future research, scholars can use in-depth interviews in addition to a questionnaire survey in order to comprehensively understand those needs. Secondly, due to the limitations of researchers' energy and time, the sample size obtained in the investigation is limited, which may not be enough to represent the whole situation of Beijing. In future studies, the sample size can be expanded to make the sample more representative.

Author Contributions: Ideas and framework-E.W.; Survey design and data collection-J.-Q.C. and J.-B.Z.; analysis and model revision-E.W. and J.-Q.C.; manuscript writing, editing, and revision-E.W. and J.-Q.C. All authors have read and agreed to the published version of the manuscript.

Funding: This research was funded by National natural science foundation of China (no. 41601129).

Conflicts of Interest: The authors declare no conflict of interest.

\section{References}

1. National Bureau of Statistics of China. The Seventeenth of Series of Reports on Economic and Social Development Achievements of the 70th Anniversary of the Founding of New China. Available online: http:// www.stats.gov.cn/ztjc/zthd/bwcxljsm/70znxc/201908/t20190815_1691418.html (accessed on 31 October 2019).

2. Qin, H. How to alleviate the "great city disease"-A critical reflection on Beijing urban planning and construction. China Anc. City 2013, 1, 16-20.

3. Roth, C.E. Environmental Literacy: Its Roots, Evolution and Directions in the 1990s; ERIC: Columbus, $\mathrm{OH}$, USA, 1992.

4. Levidow, L. What is Green Economy? Diverse Agendas, Their Tensions and Potential Futures; IKD, Open University: Walton Hall, UK, 2014.

5. Perez-Carmona, A. Growth: A discussion of the margins of economic and ecological thought. In Transgovernance Advancing Sustainability Governance; Meuleman, L., Ed.; Springer: Berlin/Heidelberg, Germany, 2011.

6. UN-Habitat. United Nations Environment Programme (UNEP). Sustainable Cities Programme 1990-2000: A Decade of United Nations Support to Broad-Ased Participatory Management of Urban Development; UN-Habitat: Nairo-bi, Kenya, 2001.

7. Zheng, F. Sustainable City Theory and Practice; People's Publishing House: Beijing, China, 2005.

8. Ma, Y. Study on Sustainability Evaluation Index of Large Urban Construction. Master's Thesis, Tianjin University, Tianjin, China, May 2018.

9. Zhao, L.; Dong, D. Evaluation of sustainable development of urban construction. J. Liaoning Univ. Technol. 2005, 1, 71-74.

10. Zhang, S. Capacity evaluation and mechanism construction of sustainable urban development. Sci. Technol. Econ. 2005, 1, 43-46.

11. Li, N.; Li, X. Research on sustainable development urban construction and evaluation. Low Temp. Archit. Technol. 2004, 5, 104-106.

12. Wang, M.; Kang, W.; Liu, J. Sustainable urban construction in China: Experience, problems and prospects. Yuejiang Acad. J. 2018, 10, 25-35.

13. Wu, Z. The concept and practice of sustainable urban construction in China. Environ. Econ. 2018, $24,46-51$.

14. Zang, X.; Wang, W. The connotation, principles and dimensions of sustainable urban design. Sci. Technol. Rev. 2019, 37, 6-12.

15. Yang, J. Sustainable transportation strategy based on healthy city concept. Urban Resid. 2019, $26,14-17$.

16. Song, Y.T. Research on the Indicator System of Life Cycle Assessment of Sustainable Urban Comprehensive Park. Ph.D. Thesis, Northeast Forestry University, Harbin, China, June 2016. 
17. Zhang, Y.J. The formation of Americans' consciousness of environmental education in 1960s. J. Northeast Norm. Univ. 2000, 4, 22-27.

18. World Commission on Environmental Development. Our Common Future; World Knowledge Press: Beijing, China, 1989; pp. 21-22.

19. Roth, C.E. Toward shaping environmental literacy for a sustainable future. ASTM Stand. News 1991, 19, 42-45.

20. Hines, J.M.; Hungerford, H.R.; Tomera, A.N. Analysis and Synthesis of research on responsible environmental behavior: A meta-analysis. J. Environ. Educ. 1986, 18, 1-8. [CrossRef]

21. Wang, M. Study on Environmental Awareness and Assessment Methods; China Environmental Science Press: Beijing, China, 1999; pp. 1-15.

22. Zeng, Z.P. Research on Theory and Measurement of Environmental Literacy. Ph.D. Thesis, Nanjing Normal University, Nanjing, China, April 2004.

23. Hill, R.J. Civic engagement and environmental literacy. N. Dir. Adult Contin. Educ. 2012, 135, 41-50. [CrossRef]

24. Taeshina, L. Impact on the Ecological Environment Protection Acts Literacy Farmer Farmland Research; Northwest Agriculture and Forestry University of Science and Technology: Xianyang, China, 2019.

25. Zhao, Y.Z. Research on the Cultivation of Agricultural College Students' Environmental Consciousness and Behavior: A Study of Hunan Agricultural University. Master's Thesis, Hunan Agricultural University, Changsha, China, December 2010.

26. Linder, A.D. Environmental Education: A Source Bookfor Educators; ERIC: Columbia, SC, USA, 1996; pp. $123-125$.

27. Liu, M.P.; Nan, L.; Li, X.Q. Impact of environmental literacy on farmers farmland ecological protection behavior. J. Arid Land Resour. Environ. 2019, 2, 53-59.

28. The Research Project Group of the Research on National Public Environmental Literacy Indicator System. In Study on the Evaluation Index System of Public Environmental Quality in China; China Environmental Science Press: Beijing, China, 2010; pp. 56-62.

29. Sun, Y. Study on Resident's environmental Behavior and Its influencing factors. Ph.D. Thesis, Dalian University of Technology, Dalian, China, October 2006.

30. Chen, D.Q.; Lou, C.W. Construction and analysis of environmental literacy evaluation system and model. J. Northeastern Univ. 2003, 2, 170-173.

31. Hong, D.Y.; Fan, Y.C. Measurement of public environmental knowledge: Presentation and testing of a local scale. J. Renmin Univ. China 2016, 4, 110-121.

32. Hong, D.Y. Measurement of environmental concern: Assessment of NEP scale application in China. Society 2006, 5, 71-92.

33. Yao, J. The Chinese Experience Verification of New Ecological Paradigm: A Case Study of Smog Pollution in Shanxi Province. Master's Thesis, Northwest Agriculture \& Forestry University, Xianyang, China, May 2019.

34. Wu, L.Q.; Zhu, Y. Revision of new ecological paradigm scale in urban student groups in China and its reliability and validity test. J. Nanjing Univ. Technol. 2017, 2, 53-61.

35. Stern, P. Toward theory of environmentally significant behavior. J. Soc. Issues 2000, 56, 407-424. [CrossRef]

36. Wang, Y. Exploration and analysis of the evolution of the concept of "environmental education". Comp. Educ. Res. 2003, 1, 18-22.

37. Hungerford, H.R.; Volk, T.L. Changing learner behavior through environmental education. J. Environ. Educ. 1990, 21, 8-21. [CrossRef]

38. Sepa. Agenda 21; China Environmental Science Press: Beijing, China, 1993; pp. 14-21.

39. IUCN World Conservation Congress. Available online: http://iucnworldconservationcongress.org/ (accessed on 31 October 2019).

40. Palmer, J.A. Environmental Education in the 21st Century: Theory, Practice, Progress and Prospect; China Light Industry Press: Beijing, China, 2002.

41. United Nations Organization for Education, Science and Culture (UNESCO). Intergovernmental Conference on Environmental Education: Final Report. In Proceedings of the Intergovernmental Conference on Environmental Education, Tbilisi, USSR, 14-16 October 1977; Available online: http://unesdoc.unesco.org/ (accessed on 31 October 2019).

42. Zhou, Y.W. Research on the Influencing Factors of Education Demand and Supply; People's Publishing House: Wuhan, China, 2011. 
43. Lippitt, L.R. An Experimental Approach to the Study of Autocracy and Democracy: A Preliminary Note. Sociometry 1938, 1, 292-300.

44. Jeffrey, M.L.; Scott, R.E. Minimising visitor impacts to protected areas: The efficacy of low impact education programmes. J. Sustain. Tour. 2007, 15, 5-27.

45. Shen, M. Investigation and Research on Environmental Education Needs of Community Residents. Ph.D. Thesis, East China Normal University, Shanghai, China, May 2015.

46. Li, W.; Zhong, Y. Problems and countermeasures in China's eco-tourism environmental education. Tour. BBS 2009, 3, 28-30.

47. Saomaki, I. Environmental Thinking; Central Compilation and Translation Press: Beijing, China, 2006 ; p. 102.

48. Li, W.; Zhong, Y. Eco-Tourism Environmental Education; China Forestry Press: Beijing, China, 2010.

49. Schramm, W.; Porter, W.E. Introduction to Communication, 2nd ed.; Peking University Press: Beijing, China, 2007; pp. 116-140.

50. Shen, M.X. Research on community residents' demand for environmental education. Master's Thesis, East China Normal University, Shanghai, China, May 2015.

51. Tao, L. Empirical research on higher education demand of senior high school students. Master's Thesis, Central China Normal University, Wuhan, China, October 2012.

52. Chen, H.J.; Jiang, R.C. Systematic analysis of individual needs in higher education and interpretation of the relationship between types of needs in higher education. Educ. Res. Tsinghua Univ. 2006, 2, 31-38.

53. Zhang, Q. Research on current situation and propaganda and education of green lifestyle of citizens. Master's Thesis, Beijing Forestry University, Beijing, China, July 2018.

54. Department of Wildlife Conservation and Nature Reserve Management, State Forestry Administration. National Natural Reserve Workbook; China Forestry Press: Beijing, China, November 2011.

55. Han, Y.; Yu, X.; Long, W. Functional area identification based on Beijing bus credit card data and points of interest. City Plan. 2016, 40, 52-60.

56. Hao, X.; Wei, X. Excavation of spatial allocation potential area of urban complex under the constraints of restrictive factors. Geogr. Inf. World 2019, 26, 74-79.

57. Beijing Bureau of Statistics. Available online: http://www.bjstats.gov.cn/rkjd/ (accessed on 31 October 2019).

58. Sina App Engine. Available online: http://salarycalculator.sinaapp.com/report/Beijing (accessed on 31 October 2019).

59. Kyle, G.; Graefe, A.; Manning, R.; Bacon, J. An examination of the relationship between leisure activity involvement and place attachment among hikers along the Appalachian Trail. J. Leis. Res. 2003, 35, $249-273$. [CrossRef]

60. Jorgensen, B.S.; Stedman, R.C. A comparative analysis of predictors of sense of place dimensions: Attachment to, dependence on, and identification with lakeshore properties. J. Environ. Manag. 2006, 79, 316327. [CrossRef]

61. Merian, S.B.; Keffreira, R.S. Comprehensive Research and Practical Guidance for Adult Learning; Huang, J., Zhang, Y., Wei, G., Eds.; Renmin University of China Press: Beijing, China, 2011.

62. Labouvie-Vief, G.; Grühn, D.; Studer, J. Dynamic integration of emotion and cognition: Equilibrium regulation in development and aging. In The Handbook of Life-Span Development; John Wiley \& Sons, Inc.: Hoboken, NJ, USA, 2010.

63. Sinnott, J.D. Complex thought and construction of the self in the face of aging and death. J. Adult Dev. 2009, 16, 155-165. [CrossRef]

64. Zhou, L. Development and Mechanism of Formal Thinking after Adulthood. Ph.D. Thesis, East China Normal University, Shanghai, China, 2017.

65. Liu, W.; Jiang, Y.; Li, X.; Pu, Y. Learning in This Way is More Effective-Introduction to Adult Learning; Yunnan University Press: Kunming, China, 2007; p. 39.

66. Zhu, H. Study on Cultivation of Contemporary College Students' Independent Consciousness. Ph.D. Thesis, Ocean University of China, Qingdao, China, May 2011.

67. Feng, J. A Study on the Independent Consciousness of Contemporary College Students. Master's Thesis, Xi'an University of Architecture and Technology, Xi'an, China, May 2013.

68. $\mathrm{Li}, \mathrm{H}$. The effect of psychological development of college students on the actual effect of moral education. J. Lv Liang Coll. 2018, 8, 91-92. 
69. Zhu, H. Fifth Media: Focus Media and Directional Communication under Wireless Marketing; Guangdong Economic Publishing House: Guangzhou, China, 2005.

70. Zhao, J. Rethinking the classification of traditional media in the new media environment. N. Media Res. 2019, $5,1-4$.

71. Mayer, F.S.; Frantz, C.M.; Bruehlman-Senecal, E.; Dolliver, K. Why Is Nature Beneficial? The Role of Connectedness to Nature. Environ. Behav. 2009, 41, 607-643. [CrossRef] 